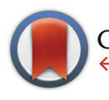

CrossMark $\leftarrow$ click for updates

Cite this: Org. Biomol. Chem., 2015, 13, 6059

Received 25th March 2015,

Accepted 29th April 2015

DOI: $10.1039 /$ c5ob00595g

www.rsc.org/obc

\title{
Selective chemical modification of DNA with alkoxy- and benzyloxyamines $\uparrow$
}

\author{
Lorina Gjonaj and Gerard Roelfes*
}

A new method for the selective chemical modification of DNA at cytosine nucleobases using alkoxy- and benzyloxyamines is presented. It is shown that in particular benzyloxyamines are effective DNA modifying agents, giving rise to almost exclusive formation of the mono addition products. By using a bifunctional derivative, that is, $p$-azidobenzyloxyamine hydrochloride, an azide moiety, which is a convenient handle for further functionalization, could be introduced into the DNA. The azido modified DNA was then further reacted in a copper(I)-monophos catalysed 1,3-dipolar cycloaddition. These results illustrate the potential of the presented method for application in site and chemo-selective modification of DNA.

\section{Introduction}

The unique chemical and physical properties of DNA have paved the way for widespread application of this molecule far beyond its natural role as carrier of genetic information. The selective recognition of complementary nucleobases, resulting in Watson-Crick base pairing, has proven to be a very powerful tool for the assembly of complex DNA structures. ${ }^{1}$ For many applications, however, additional chemical functionalities need to be introduced into the DNA. Functionalized DNAs have found applications in diverse fields such as nanotechnology, synthesis and catalysis and chemical biology, for example as DNA sensors, for electrochemical analysis, ${ }^{2}$ DNA labelling, ${ }^{3}$ DNA-based catalysis, ${ }^{4}$ hybrid materials and drug delivery systems ${ }^{5}$ and many more.

The most common method used for the preparation of functionalized DNAs involves solid phase synthesis, which is convenient for obtaining small quantities of short oligonucleotides containing novel functionalities. ${ }^{6}$ Another popular approach for the preparation of functionalized DNA involves the enzymatic incorporation of modified nucleotide triphosphates (dNTPs) by DNA polymerases. ${ }^{7}$

Both these approaches have in common that they require multistep chemical synthesis of the necessary nucleotide building blocks, which is laborious and time consuming. Ideally, it would be possible to introduce a novel chemical functionality selectively in the DNA in a post-(bio)-synthetic step. The fact that DNA is built up from only 4 building blocks

Stratingh Institute for Chemistry, University of Groningen, Nijenborgh 4, 9747 AG Groningen, The Netherlands. E-mail:j.g.roelfes@rug.nl; http://roelfesgroup.nl $\dagger$ Electronic supplementary information (ESI) available. See DOI: 10.1039/ c5ob00595g that present very similar functional groups makes this a highly challenging task.

One example of such an approach is the sequence specific modification of DNA by use of DNA methyltransferase. ${ }^{8}$ While this method has enormous potential, it again relies on synthetic nucleotides, that are, $S$-adenosyl methionine derivatives. ${ }^{9}$

A limited number of methods for the selective chemical modification of DNA have been developed. This includes bioorthogonal labelling of 5-hydroxymethylcytosine, ${ }^{10}$ selective DNA G-quadruplex alkylating agents, ${ }^{11}$ reaction of cytosine with bisulfite followed by transamination, ${ }^{12}$ selective alkylation of exocyclic amines with rhodium and copper carbenoid complexes,${ }^{13}$ and using cisplatin as a covalent anchor for catalytically active metal complexes. ${ }^{4 a, 14}$

Alkoxyamines are frequently used in bioconjugation reactions, also to DNA, albeit that this generally involves reactions with an introduced bio-orthogonal aldehyde moiety, resulting in oxime formation. ${ }^{15}$ However, hydroxyl and methoxyamines have long been known to modify DNA selectively. This is, for example, the foundation for their use as mutagenic agents and in Maxam-Gilbert sequencing. ${ }^{16}$

Both hydroxyl- and methoxyamine react specifically and hundred times more efficiently with exposed cytosine residues compared to the other three nucleobases. ${ }^{17}$ The main products of this reaction are the result of nucleophilic attack on either C4 or C6, which are the most electrophilic positions. At high concentrations of alkoxyamine, commonly the C4 substitution product $\mathrm{A}$ and the double addition product $\mathrm{B}$ are obtained as the main products (Scheme 1). The efficiency and the selectivity of the reaction are dependent on the $\mathrm{pH}$, temperature and concentration. ${ }^{18}$ Here we report that alkoxyamines, and in particular benzyloxyamines, are excellent reagents for the selective mono-functionalization of cytosine in DNA. Moreover, we show that by using a bifunctional benzyloxyamine derivative 
<smiles>[R]n1ccc(N)nc1=O</smiles><smiles>[R]C(C)CC(C)=O</smiles><smiles>[R]ONc1ccn([R])c(=O)n1</smiles>

(A)<smiles>[R]ONC1=NC(=O)N([R])C(NO[R])C1</smiles>

(B)
Scheme 1 Reaction of hydroxylamine and methoxyamine with cytosine.

containing an azide moiety, further functionalization of DNA can be achieved using azide-alkyne click chemistry.

\section{Results and discussion}

\section{Synthesis of alkoxyamines}

The alkoxyamines hydrochloride salts 1-7 were used in this study (Fig. 1). 1, 5 and 6 were available from commercial sources, 3 and $\mathbf{4}$ were prepared following literature procedures. ${ }^{19}$

2 was prepared from decyl bromide $(\mathbf{8})$ by reaction with $N$-hydroxyphtalamide in the presence of $\mathrm{K}_{2} \mathrm{CO}_{3}$ giving rise to 9 (Scheme 2). This was followed by reaction with hydrazine hydrate, resulting in the free alkoxyamine 10. Treatment of $\mathbf{1 0}$ with $\mathrm{HCl}[6 \mathrm{M}]$ provided 1-decylhydroxylamine hydrochloride salt 2.

Azide modified benzyloxyamine 7 was prepared using the synthetic route outlined in Scheme 3. p-Azido-toluene (12) was prepared by reacting $p$-toluidine (11) with $\mathrm{NaNO}_{2} / \mathrm{HCl}$ and $\mathrm{NaN}_{3}$. The subsequent bromination reaction was performed using NBS and AIBN, which did not result in full conversion, even after 3 days. Treatment of $\mathbf{1 3}$ with $N$-hydroxyphtalamide in presence of a base yielded 14, which possessed the aminoxy functionality. Deprotection of $\mathbf{1 4}$ with hydrazine hydrate furnished the free alkoxyamine, which was transformed immediately to the corresponding hydrochloride salt 7 .

\section{DNA modification with alkoxyamines}

The optimal reaction conditions for DNA modification were investigated in the reaction of $O$-methoxyamine $\cdot \mathrm{HCl}(\mathbf{1})$ with a

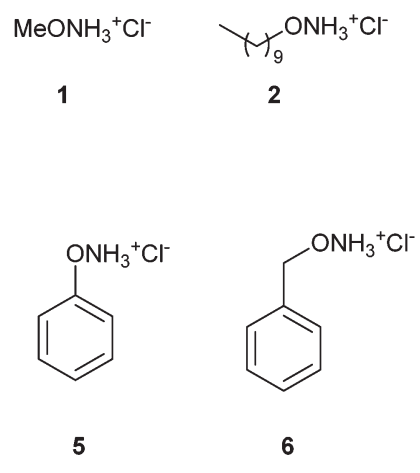

$$
\begin{gathered}
\mathrm{Cl}^{-} \mathrm{H}_{3} \mathrm{~N}^{+}+\mathrm{ONH}_{3}{ }^{+} \mathrm{Cl}^{-} \\
\text {3: }(\mathrm{n}=1) \\
\mathbf{4}(\mathrm{n}=3)
\end{gathered}
$$

Fig. 1 Alkoxyamines used in this study.

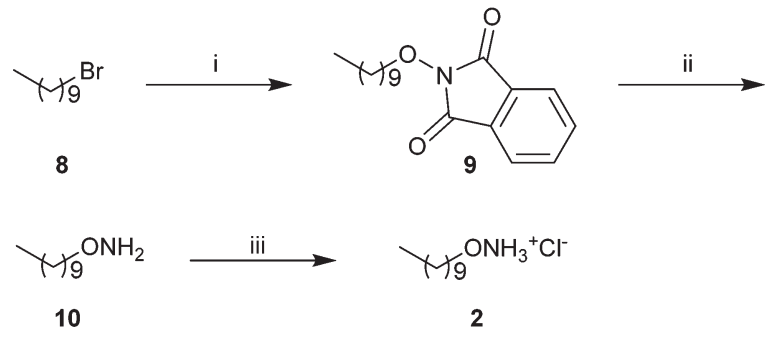

Scheme 2 Synthesis of 2. (i) $\mathrm{N}$-Hydroxyphtalamide, $\mathrm{K}_{2} \mathrm{CO}_{3}, \mathrm{DMF}$, overnight, $83 \%$; (ii) hydrazine hydrate, DCM, overnight, $69 \%$; (iii) $10 \mathrm{M} \mathrm{HCl}$, quantitative.

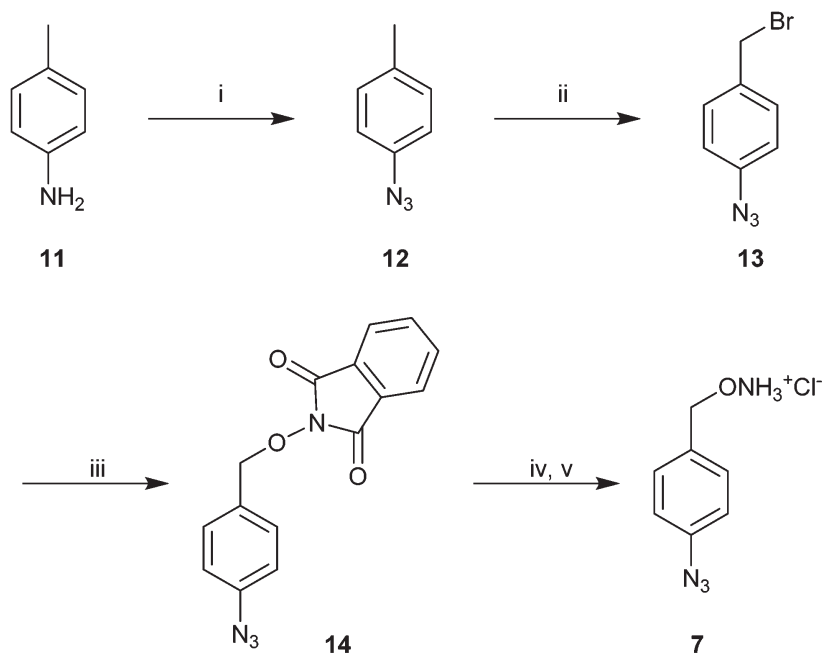

Scheme 3 Synthesis of azido modified benzyloxyamine 7. (i) $\mathrm{NaNO}_{2}$, $\mathrm{HCl}, \mathrm{NaN}_{3}, \mathrm{H}_{2} \mathrm{O}, 85 \%$; (ii) NBS, AIBN, benzene, 3 days, 69\%; (iii) N-hydroxyphtalamide, $\mathrm{K}_{2} \mathrm{CO}_{3}, \mathrm{DMF}$, overnight, 76\%; (iv) hydrazine hydrate, DCM, overnight, $56 \%$; v. Conc. $\mathrm{HCl}$, quantitative.

single stranded DNA pentamer with sequence dTACGT (O1), containing only one cytosine. This reaction gives rise to 2 possible products: the mono-substituted adduct A and double substituted product B. A first screening of conditions revealed that the shortest reaction time and optimal selectivity was achieved at $\mathrm{pH}=4$ and a reaction temperature of $50{ }^{\circ} \mathrm{C}$ (Table $\mathrm{S} 1 \dagger$ ). Next, the dependence on the concentration of $\mathbf{1}$ was determined (Table 1). The highest ratio $\mathrm{A} / \mathrm{B}$, i.e. $\mathrm{A} / \mathrm{B}=12$, was obtained at a final concentration of 1 of $0.5 \mathrm{M}$ (entry 3), but with relatively low conversions after $8 \mathrm{~h}$. A longer reaction time resulted in almost full conversion, albeit accompanied by a small decrease in selectivity (entry 4). Lowering the concentration of $\mathbf{1}$ further resulted in a decrease of both the ratio $\mathrm{A} / \mathrm{B}$ and the reaction rate. Therefore it was concluded that the optimal conditions to achieve both high conversion and high selectivity were $\mathrm{pH}=4.0,50^{\circ} \mathrm{C}$ and final concentration of $0.5 \mathrm{M}$ of the methoxyamine (Table 1 , entry 4 ). The products were purified using reversed phase HPLC and their identity was confirmed by MALDI-TOF (A $m / z=1507$ and B $m / z=1554$, respectively). 
Table 1 Optimization of the reaction of 1 with oligo $1^{a}$

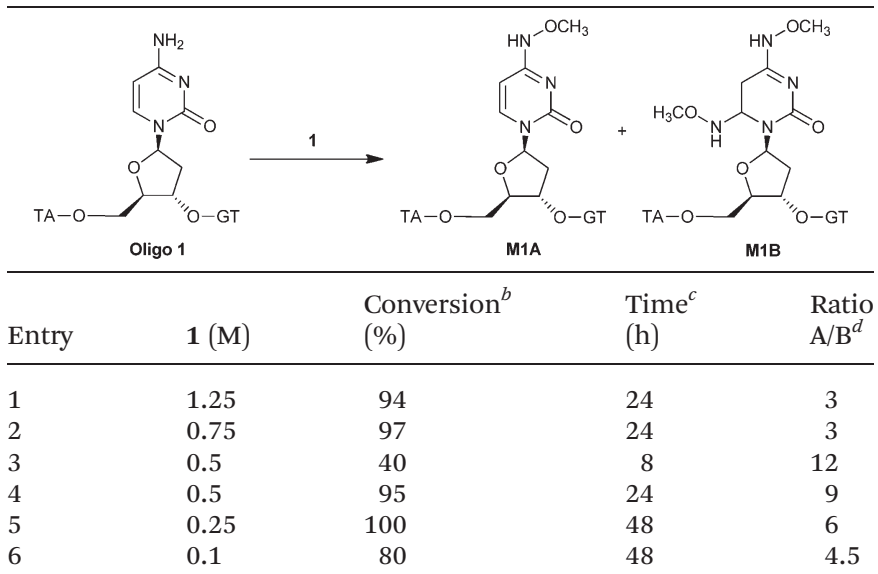

${ }^{a}$ All experiments were carried out in the presence of oligo $1[100 \mu \mathrm{M}]$, methoxyamine $\mathbf{1}\left(\mathrm{pH}=4\right.$ and $\left.50{ }^{\circ} \mathrm{C}\right) .{ }^{b}$ Determined by RP-HPLC. ${ }^{c}$ Time after which the samples were taken. ${ }^{d}$ Determined with RP-HPLC.

Having established the optimal conditions for modifying DNA with 1, the scope of the reaction was explored using a variety of other alkoxyamines. First the alkoxyamines 2-4 were investigated. 2 contains a long alkyl chain and the DNA adduct potentially can be used for the synthesis of DNA surfactants, which have found applications in nanotechnology. ${ }^{20}$ After optimization it was found that at room temperature (r.t) and at $0.45 \mathrm{M}$ methoxyamine concentration gave the best result with a ratio A/B of $4: 1$ (Table $\mathrm{S} 2 \dagger$ ).

Amino modified DNAs are useful scaffolds for derivatization. $^{3}$ The goal here was to modify the DNA with an amino functionality using amino alkoxyamines. The DNA functionalization with aminoxy aminoalkyl dihydrochlorides, $\mathbf{3}$ and $\mathbf{4}$, was investigated using the optimized conditions found for $\mathbf{1}$. Unfortunately, in both cases the reaction times were significantly longer and many unidentified side products were obtained. Even when the final concentration of the modifying agents was increased to $1.0 \mathrm{M}$, full conversion was not obtained after 5 days. The corresponding mono-substituted products were observed, but due to the fact that the reaction results in complex product mixtures, this reaction was not pursued further.

\section{DNA modification with benzyloxyamines}

In light of the results described above, it was decided to focus on aryloxy- and benzyloxyamines. Phenyloxyamine hydrochloride 5 gave no reaction, even after several days. This suggests that this reagent is not sufficiently nucleophilic. In contrast, excellent results were achieved using benzyloxyamine hydrochloride 6. After $48 \mathrm{~h}$, the reaction had almost reached completion (97\% conversion) and the desired mono-substituted product A was obtained as the major product with an A/B ratio of $12: 1$ (Table 2, entry 2). Increasing the final concentration of the alkoxyamine, resulted in a lower ratio compared to entry
Table 2 Reaction of oligo 1 with aryl and benzyloxyamines ${ }^{a}$

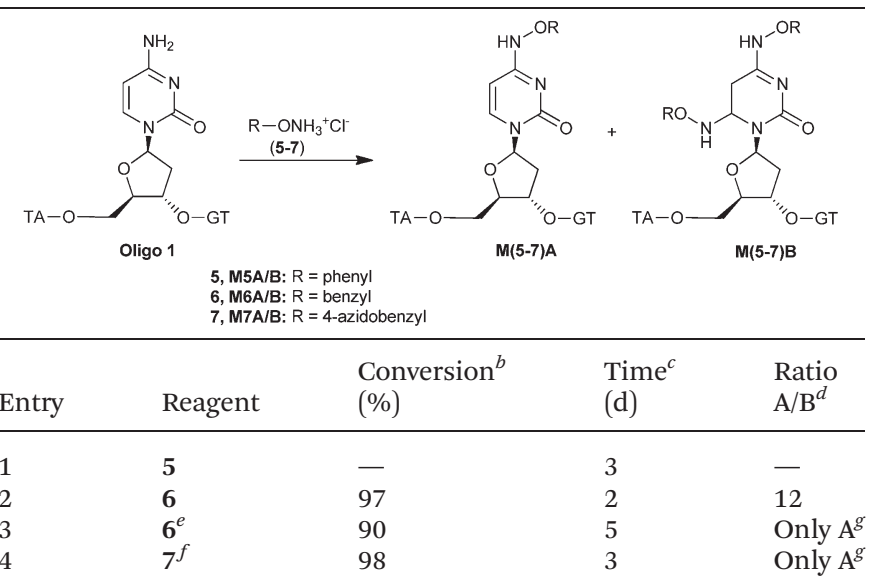

${ }^{a}$ All experiments were carried out with oligo $1[100 \mu \mathrm{M}]$ and a final concentration of alkoxyamine reagent of $0.5 \mathrm{M}$, at $\mathrm{pH}=4$ and $50{ }^{\circ} \mathrm{C}$, unless noted otherwise. ${ }^{b}$ Determined by RP-HPLC. ${ }^{c}$ Time after which the samples were taken. ${ }^{d}$ Ratio mono/double substituted products, determined by RP-HPLC. ${ }^{e}$ Reaction with oligo $2[100 \mu \mathrm{M}] .{ }^{f}$ Final concentration of compound $70.25 \mathrm{M} .{ }^{g}$ Disubstituted product B was not detected.

2. The product was purified by reversed phase-HPLC, giving rise to $12 \%$ isolated yield.

The product M6A was subjected to an MS/MS analysis to verify that indeed the cytosine had been modified selectively (Fig. S2 $\dagger$ ). Assignment of the peaks resulting from the small fragments of the product confirmed the presence of unmodified A, G and T nucleobases; no peaks corresponding to any of these bases carrying the benzyloxyamino functionality were found. However, unmodified cytosine fragments were not observed after fragmentation. Instead, a fragment with $\mathrm{m} / \mathrm{z}=$ 216.1 was found which corresponds to the benzyloxyamino modified cytosine nucleobase. Moreover, analysis of the larger fragments confirmed that A, T and G were not modified (ESI $\dagger$ ). Additionally, the assignment of fragments at $m / z 1110.6$ and 1279 supports modification at $\mathrm{C}$.

Given the success of modifying oligo 1 with benzyloxyamine hydrochloride a longer sequence of DNA was tested. The reaction with oligo 2 (dAATACGTG) was investigated using the optimized conditions. The reaction was found to be highly selective, i.e. the double substituted product could not be detected, but slow (Table 2, entry 3 ). After 5 days, 90\% conversion was obtained, as determined by HPLC. The product was purified by preparative RP-HPLC and its identity was confirmed by MALDI-TOF $(m / z=2534)$.

\section{DNA modification with a bifunctional benzyloxyamine}

Having established the efficient and selective modification of DNA with benzyloxyamine, we focused on using the bifunctional benzyloxyamine derivative 7 , carrying an azide moiety that can be used for further functionalization. The reaction was followed by RP-HPLC and analysed by MALDI-TOF. Full conversion was obtained after 3 days at $50{ }^{\circ} \mathrm{C}$. The 


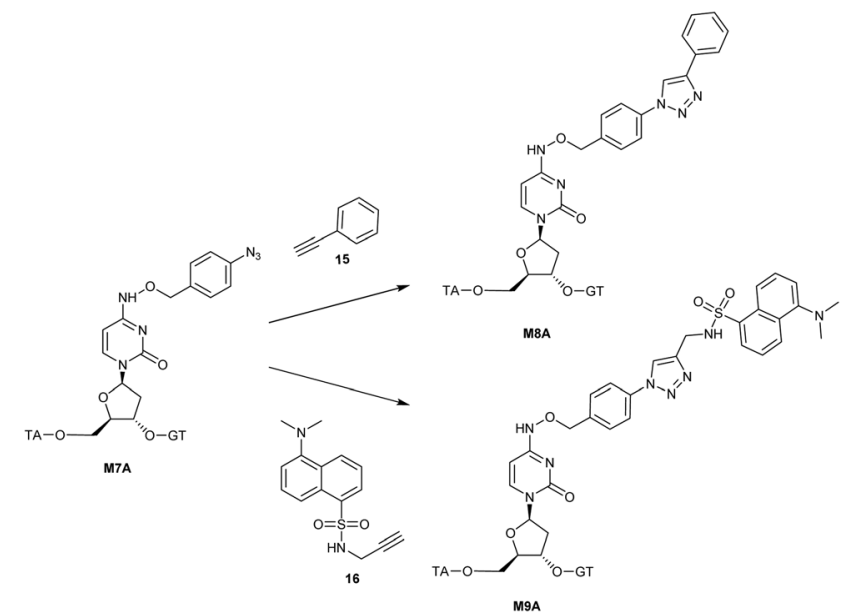

Scheme 4 Click reaction of M7A. Conditions: $\mathrm{CuSO}_{4}$ : monophos: sodium ascorbate (1:1.1:10) (5 mol\% copper), excess of alkyne.

modification process was highly selective towards the monosubstituted product $\mathbf{M 7 A}$, i.e. formation of the disubstituted product M7B was not observed. M7A was purified by size exclusion chromatography (75-80\% yield).

The azide functionality can be reacted further using either the Huisgen 1,3-dipolar cycloaddition. ${ }^{21}$ Thus, DNA labelled with an azide moiety is an attractive building block for introducing fluorophores, carbohydrates and ligation to other biomolecules. $^{22}$ The copper catalysed azide-alkyne cycloaddition procedure that was applied involves a recently reported copper-monophos catalyst, which has been shown to significantly accelerate the reaction. ${ }^{23}$ This procedure is compatible with peptides and enzymes and it can be performed in aqueous media. The reaction was explored using two different alkynes (Scheme 4), phenylacetylene 15 and the fluorescent alkyne 16, a derivate of dansyl chloride.

Copper(II) sulphate was used as the copper source, which was reduced to $\mathrm{Cu}(\mathrm{I})$ in situ by sodium ascorbate. The mixture of copper and ligand was added to the solution of the alkyne and azide, under nitrogen atmosphere. The click reactions were followed by reversed phase. Full conversion was achieved within 2 hours in both reactions. The DNA functionalized products, M8A and M9A, were obtained after preparative HPLC in isolated yields of $14-15 \%$ over 2 steps.

\section{Conclusions}

A new method for the selective chemical modification of DNA at cytosine nucleobases using alkoxy- and benzyloxyamines was developed. The most effective modifying agents were found to be benzyloxyamines, which proved to give almost exclusively formation of the mono addition products. By using a bifunctional derivative, that is, $p$-azidobenzyloxyamine hydrochloride, an azide moiety, which is a convenient handle for further functionalization, could be introduced into the
DNA. The azido modified DNA was then further reacted in a copper(I)-monophos catalysed 1,3-dipolar cycloaddition. This illustrates the potential of the presented method for application to site and chemo-selective modification of DNA.

\section{Experimental}

\section{General remarks}

Reagents were purchased from Aldrich or Fluka and they were used as received. ${ }^{1} \mathrm{H}-\mathrm{NMR}$ and ${ }^{13} \mathrm{C}-\mathrm{NMR}$ spectra were recorded on a Varian AMX400 (400 and $100 \mathrm{MHz}$ ) in $\mathrm{CDCl}_{3}$. Reversed phase-HPLC (RP-HPLC) analysis were performed on a Shimadzu LC-10AD VP, Waters Xterra MS C18 column $(3.0 \times$ $150 \mathrm{~mm}$, particle size $3.5 \mu \mathrm{m}$ ) using a gradient of $\mathrm{CH}_{3} \mathrm{CN} / \mathrm{TEAA}$ (triethylammonium acetate) buffer $50 \mathrm{mM} \mathrm{pH}=7$ at $40{ }^{\circ} \mathrm{C}$ For purification purposes Waters Xterra Prep MS C18 column

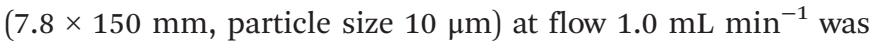
used. Gradient A (general gradient unless noted otherwise): $\mathrm{CH}_{3} \mathrm{CN} / \mathrm{TEAA}$ buffer $50 \mathrm{mM} \mathrm{pH}=7$; gradient: 05/95 0 to $10 \mathrm{~min}$, to $10 / 90$ at $15 \mathrm{~min}$, to $20 / 80$ at $20 \mathrm{~min}$ to $30 / 70$ at $30 \mathrm{~min}$, to $50 / 50$ at $50 \mathrm{~min}$ to $70 / 30$ at 65 to $05 / 95$ at $95 \mathrm{~min}$ for

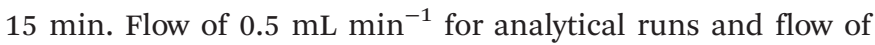
$1.0 \mathrm{~mL} \mathrm{~min}^{-1}$ for the preparative runs. MALDI-TOF measurements were done on a Voyager-DE Pro apparatus (Matrix: $20 \mu \mathrm{L}$ of a solution of 2,4,6-trihydroxyacetophenone $0.5 \mathrm{M}$ in EtOH + $10 \mu \mathrm{L}$ of a solution of ammonium citrate dibasic $0.1 \mathrm{M}$ in double distilled (dd) $\mathrm{H}_{2} \mathrm{O}+2 \mu \mathrm{L}$ sample solution in dd $\mathrm{H}_{2} \mathrm{O}$ ). HRMS spectra were recorded on a LTQ XL Orbitrap from Thermo Fisher Scientific. Oligo 1 (dTACTG) and oligo 2 (dAATACGTG) were obtained from BioTez Berlin. Oligonucleotide concentrations were determined using Nanodrop ND-100 from Thermo Fisher Scientific. Column chromatography was performed on silica gel.

\section{Synthesis of alkoxy amines}

2-(Decyloxy)isoindoline-1,3-dione (9). To a solution of 1-bromodecane $8(2.2 \mathrm{~g}, 10.0 \mathrm{mmol})$ and $N$-hydroxyphtalamide $(1.96 \mathrm{~g}, 12.0 \mathrm{mmol})$ in $50 \mathrm{~mL} \mathrm{DMF}, \mathrm{K}_{2} \mathrm{CO}_{3}(1.66 \mathrm{~g}, 12 \mathrm{mmol})$ was added in two portions. The reaction mixture was allowed to react overnight at room temperature. The solvent was evaporated under reduced pressure. The resulting solid was dissolved in dichloromethane $(100 \mathrm{~mL})$ and washed with $\mathrm{H}_{2} \mathrm{O}$ $(100 \mathrm{~mL})$. After separation, the organic layer was washed with $\mathrm{H}_{2} \mathrm{O}(2 \times 30 \mathrm{~mL})$ and with brine $(2 \times 30 \mathrm{~mL})$. The organic layer was dried over $\mathrm{MgSO}_{4}$ and concentrated under pressure to give 9 as white solid (2.54 g, $8.3 \mathrm{mmol}, 83 \%$ yield) ${ }^{1} \mathrm{H}$ NMR $\left(400 \mathrm{MHz}, \mathrm{CDCl}_{3}\right): \delta 7.83-7.86(\mathrm{~m}, 2 \mathrm{H}), 7.73-7.75(\mathrm{~m}, 2 \mathrm{H}), 4.19$ $(\mathrm{t}, J=6.8 \mathrm{~Hz}, 2 \mathrm{H}), 1.79(\mathrm{~m}, 2 \mathrm{H}), 1.45(\mathrm{~m}, 2 \mathrm{H}), 1.19-1.35$ $(\mathrm{m}, 12 \mathrm{H}), 0.87$ (t, $J=6.6 \mathrm{~Hz}, 3 \mathrm{H}) .{ }^{13} \mathrm{C} \mathrm{NMR}\left(101 \mathrm{MHz}, \mathrm{CDCl}_{3}\right)$ : $\delta 163.7,134.4,129.0,123.5,78.6,31.9,29.5,29.46,29.44,29.3$, 28.1, 25.5, 22.7, 14.1. HRMS (positive mode) $(\mathrm{m} / \mathrm{z})$ calculated mass for $\mathrm{C}_{18} \mathrm{H}_{25} \mathrm{~N}_{1} \mathrm{O}_{3} \mathrm{Na}[\mathrm{M}+\mathrm{Na}]^{+} 326.17266$, found mass 326.17242. $\mathrm{mp}=72-73^{\circ} \mathrm{C}$.

O-Decylhydroxylamine (10). To a solution of 9 (2.12 g, $7.0 \mathrm{mmol}$ ) in $30 \mathrm{~mL}$ of dichloromethane, hydrazine hydrate 
(0.7 mL, $14 \mathrm{mmol}$ ) was added drop wise. After stirring overnight, the reaction was quenched with $\mathrm{NaOH}\left[\begin{array}{ll}1 & \mathrm{M}\end{array}\right]$. The organic layer was washed with $\mathrm{H}_{2} \mathrm{O}(2 \times 30 \mathrm{~mL})$, brine $(2 \times 30 \mathrm{~mL})$, dried over $\mathrm{MgSO}_{4}$ and concentrated under reduced pressure. The crude solid was further purified by column chromatography ( $n$-hexane : ethyl acetate, $7: 3$ ) to give 10 as a colorless oil (0.83 g, $4.8 \mathrm{mmol} .69 \%$ yield). ${ }^{1} \mathrm{H}$ NMR $\left(400 \mathrm{MHz}, \mathrm{CDCl}_{3}\right): \delta 5.34$ (br s, $2 \mathrm{H}-\mathrm{ONH}_{2}$ ), $3.65(\mathrm{t}, J=6.7 \mathrm{~Hz}$, $2 \mathrm{H}), 1.57(\mathrm{~m}, 2 \mathrm{H}), 1.18-1.39(\mathrm{~s}, 14 \mathrm{H}), 0.88(\mathrm{t}, J=6.6 \mathrm{~Hz}, 3 \mathrm{H})$. ${ }^{13} \mathrm{C}$ NMR (101 MHz, $\mathrm{CDCl}_{3}$ ): $\delta$ 76.3, 32.0, 29.7, 29.6, 29.6, 29.4, 28.4, 26.1, 22.7, 14.5. HRMS (positive mode) $(\mathrm{m} / \mathrm{z})$ calculated mass for $\mathrm{C}_{10} \mathrm{H}_{24} \mathrm{NO}[\mathrm{M}+\mathrm{H}]^{+} 174.18524$, found mass 174.18518.

The product was immediately converted to the corresponding hydrochloride salt by treatment with of $\mathrm{HCl}\left[\begin{array}{l}6 \mathrm{M}\end{array}\right]$. After filtration, the white solid was lyophilized.

1-Azido-4-methylbenzene (12). Prepared following published procedure. ${ }^{24} 10 \mathrm{~g}(92.8 \mathrm{mmol})$ of $p$-toluidine was dissolved in $46 \mathrm{~mL}$ of a solution of $\mathrm{H}_{2} \mathrm{O}: \mathrm{HCl}(1: 1)$ at $0{ }^{\circ} \mathrm{C}$. Sodium nitrite $(6.3 \mathrm{~g}, 92.8 \mathrm{mmol})$ dissolved in $26 \mathrm{~mL}$ of cold $\mathrm{H}_{2} \mathrm{O}$ was added drop wise, followed by drop wise addition of sodium azide $(6.1 \mathrm{~g}, 92.8 \mathrm{mmol})$ in $58 \mathrm{~mL} \mathrm{H}_{2} \mathrm{O}$. After $1 \mathrm{~h}$ $\mathrm{CHCl}_{3}(100 \mathrm{~mL})$ was added. The aqueous phase was extracted twice with $\mathrm{CHCl}_{3}(100 \mathrm{~mL})$. The combined organic layers were washed with $\mathrm{H}_{2} \mathrm{O}(2 \times 30 \mathrm{~mL})$ and dried over $\mathrm{MgSO}_{4}$, concentrated under pressure to give $\mathbf{1 2}$ as a brown oil (11.1 g, $79.1 \mathrm{mmol}, 85 \%) .{ }^{1} \mathrm{H}$ NMR (400 $\mathrm{MHz}, \mathrm{CDCl}_{3}$ ): $\delta 7.17$ (d, $J=$ $8.0 \mathrm{~Hz}, 2 \mathrm{H}), 6.94(\mathrm{~d}, J=8.0 \mathrm{~Hz}, 2 \mathrm{H}), 2.35$ (s, 3H). ${ }^{13} \mathrm{C}$ NMR (101 MHz, $\left.\mathrm{CDCl}_{3}\right): \delta 137.1,134.86,130.3,118.7,20.5$.

1-Azido-4-(bromomethyl)benzene (13). Prepared following a published procedure. ${ }^{25}$ To a solution of 1-azido-4-methylbenzene (12) (7.14 g, $53.7 \mathrm{mmol})$ in benzene $200 \mathrm{~mL}$ under a nitrogen atmosphere, $N$-bromosuccinimide $(10.51 \mathrm{~g}, 59 \mathrm{mmol})$ and AIBN $1.0 \mathrm{~g}$ were added. The reaction was heated under reflux for 3 days. The solvent was evaporated under reduced pressure. The resulting solid was dissolved in $\mathrm{CH}_{2} \mathrm{Cl}_{2}$ $(100 \mathrm{~mL})$. The organic layer was washed with $\mathrm{H}_{2} \mathrm{O}(2 \times 30 \mathrm{~mL})$ and brine $(2 \times 30 \mathrm{~mL})$, dried over $\mathrm{MgSO}_{4}$ and concentrated under reduced pressure to give the crude product which was further purified by column chromatography (petroleum ether) to give 13 as a brown oil (7.8 g, $37.1 \mathrm{mmol}, 69 \%) .{ }^{1} \mathrm{H}$ NMR $\left(400 \mathrm{MHz}, \mathrm{CDCl}_{3}\right): \delta 7.39(\mathrm{~d}, J=12.4 \mathrm{~Hz}, 2 \mathrm{H}), 7.01(\mathrm{~d}, J=$ $12 \mathrm{~Hz}, 2 \mathrm{H}), 4.48$ (s, 2H). ${ }^{13} \mathrm{C}$ NMR (101 MHz, CDCl3) $\delta=139.9$, 134.2, 130.6, 119.3, 32.9.

2-((4-Azidobenzyl)oxy)-isoindoline-1,3-dione (14). To a solution of 1-azido-4-(bromomethyl)benzene 13 (3.4 g, $16 \mathrm{mmol}$ ) and $N$-hydroxyphtalamide $(3.13 \mathrm{~g}, 19.2 \mathrm{mmol})$ in $50 \mathrm{~mL} \mathrm{DMF}$, $\mathrm{K}_{2} \mathrm{CO}_{3}(2.65 \mathrm{~g}, 19.2 \mathrm{mmol})$ was added in two portions. The reaction mixture reacted overnight. The solvent was evaporated under reduced pressure. The resulting solid was partitioned in $\mathrm{CH}_{2} \mathrm{Cl}_{2}(150 \mathrm{~mL})$ and $\mathrm{H}_{2} \mathrm{O}(100 \mathrm{~mL})$. The organic layer after isolation, it was washed with brine $(2 \times 50 \mathrm{~mL})$ and then it was dried over $\mathrm{MgSO}_{4}$, concentrated under reduced pressure to give 14 as a brown solid (3.5 g, $12.16 \mathrm{mmol}, 76 \%) .{ }^{1} \mathrm{H}$ NMR $\left(400 \mathrm{MHz}_{\mathrm{CDCl}}\right)$ ): $\delta 7.87-7.69(\mathrm{~m}, 4 \mathrm{H}), 7.52(\mathrm{~d}, J=7.2 \mathrm{~Hz}, 2 \mathrm{H})$, 7.02 (d, $J=7.4 \mathrm{~Hz}, 2 \mathrm{H}), 5.17$ (s, 2H). ${ }^{13} \mathrm{C}$ NMR $(101 \mathrm{MHz}$,
$\left.\mathrm{CDCl}_{3}\right): \delta 163.3,141.1,134.5,131.4,130.1,128.6,123.4$, 119.0, 78.8. HRMS (positive mode) $(\mathrm{m} / \mathrm{z})$ calculated mass for $\mathrm{C}_{15} \mathrm{H}_{10} \mathrm{~N}_{4} \mathrm{O}_{3} \mathrm{Na}[\mathrm{M}+\mathrm{Na}]^{+} 317.06451$, found mass 317.06436 $\mathrm{mp}=163-164^{\circ} \mathrm{C}$.

O-(4-Azidobenzyl) hydroxylamine (15). To a solution 2-((4-azidobenzyl)oxy)-isoindoline-1,3-dione 14 (3.2 g, $10.9 \mathrm{mmol})$ in $45 \mathrm{ml}$ of $\mathrm{CH}_{2} \mathrm{Cl}_{2}$, hydrazine hydrate $(1.04 \mathrm{~mL}, 33 \mathrm{mmol})$ was added drop wise. After stirring overnight the reaction was quenched with $\mathrm{NaOH}[1 \mathrm{M}]$. The organic layer was washed with $\mathrm{H}_{2} \mathrm{O}(2 \times 30 \mathrm{~mL})$ and brine $(2 \times 30 \mathrm{~mL})$. The organic phase was dried over $\mathrm{MgSO}_{4}$ and concentrated under reduced pressure to give 15 as yellow-brownish oil $(1.1 \mathrm{~g}, 6.1 \mathrm{mmol}$, $56 \%) .{ }^{1} \mathrm{H}$ NMR (400 MHz, $\left.\mathrm{CDCl}_{3}\right): \delta 7.36(\mathrm{~d}, J=8.2 \mathrm{~Hz}, 2 \mathrm{H}$ ), 7.03 (d, $J=8.0 \mathrm{~Hz}, 2 \mathrm{H}), 5.41$ (br s, 2H $\left.-\mathrm{ONH}_{2}\right), 4.65(\mathrm{~s}, 2 \mathrm{H})$. ${ }^{13} \mathrm{C}$ NMR (101 MHz, $\left.\mathrm{CDCl}_{3}\right): \delta$ 139.7, 134.4, 129.9, 119.0, 77.2. HRMS (positive mode) $(\mathrm{m} / \mathrm{z})$ calculated mass for $\mathrm{C}_{7} \mathrm{H}_{9} \mathrm{~N}_{4} \mathrm{O}$ $[\mathrm{M}+\mathrm{H}]^{+}$165.07709, found mass 165.07690.

The product was immediately converted to the corresponding hydrochloride salt by treatment with of $\mathrm{HCl}\left[\begin{array}{l}6 \mathrm{M} \\ \text { ] }\end{array}\right.$ After filtration, the yellow solid was lyophilized.

\section{DNA modifications}

Stock solutions of reagents. The hydrochloride salts (compounds 1-7) were dissolved in double distilled (dd) $\mathrm{H}_{2} \mathrm{O}$ and brought to the desired $\mathrm{pH}$ by using $\mathrm{NaOH}\left[\begin{array}{ll}6 & \mathrm{M}\end{array}\right]$. The stock solutions were stored at $-20^{\circ} \mathrm{C}$.

The oligonucleotides were dissolved in $\mathrm{dd}_{2} \mathrm{O}$ (final concentrations of $200 \mu \mathrm{M}$ ). The concentrations of the oligonucleotides were determined from their UV/Vis absorptions at $260 \mathrm{~nm}$ (Nanodrop) using the calculated extinction coefficients.

Modification of oligo 1 with $\mathrm{CH}_{3} \mathrm{ONH}_{2} \cdot \mathrm{HCl}$; representative procedure. $100 \mu \mathrm{L}$ of oligo 1 was mixed with $100 \mu \mathrm{L}$ of the desired solution of methoxyamine hydrochloride (for final concentrations see Table 1) at the indicated temperatures for the indicated times. The products were purified by preparative reversed phase HPLC (Xterra column gradient B was used: $\mathrm{CH}_{3} \mathrm{CN} / \mathrm{TEAA}$ buffer $50 \mathrm{mM} \mathrm{pH}=7$; gradient: 05/95 0 to $10 \mathrm{~min}$, to $10 / 90$ at $15 \mathrm{~min}$, to $20 / 80$ at $20 \mathrm{~min}$ to $30 / 70$ at $30 \mathrm{~min}$, to $50 / 50$ at $50 \mathrm{~min}$ to $70 / 30$ at 65 to $05 / 95$ at $95 \mathrm{~min}$ for $15 \mathrm{~min}$ ); flow of $0.5 \mathrm{~mL} \mathrm{~min}^{-1}$ for analytical runs and flow of $1.0 \mathrm{~mL} \min ^{-1}$ for the preparative column.) and the pure fractions were lyophilized.

Purity of the samples was evaluated with analytical reversed phase HPLC (gradient A) and the identity was confirmed with MALDI-TOF:

M1A: Retention time $33.3 \mathrm{~min}$. MALDI-TOF $(\mathrm{m} / \mathrm{z})$ found 1507 (calculated 1506).

M1B: Retention time $34.2 \mathrm{~min}$. MALDI-TOF $(\mathrm{m} / \mathrm{z})$ found 1554 (calculated 1553).

Reaction of oligo 1 with 2. $100 \mu \mathrm{L}$ of oligo 1 solution was mixed with the desired volume (for final concentrations, see Table 2) of $O$-decylhydroxylamine hydrochloride $5\left(\left[\begin{array}{ll}0.7 & \mathrm{M}\end{array}\right]\right.$, $\mathrm{pH}=4)$. The reaction was followed by RP-HPLC and purified using a preparative Xterra column. Gradient $\mathrm{C}$ was used: $\mathrm{CH}_{3} \mathrm{CN} /$ TEAA buffer $50 \mathrm{mM} \mathrm{pH}=7$; gradient: 05/95 0 to $10 \mathrm{~min}$, to 
$35 / 65$ at $40 \mathrm{~min}$, to $70 / 30$ at $50 \mathrm{~min}$ to $05 / 95$ at $55 \mathrm{~min}$ for $15 \mathrm{~min}$. Flow: $0.5 \mathrm{~mL} \mathrm{~min}^{-1}$ for analytical runs and flow of $1.0 \mathrm{~mL} \mathrm{~min}^{-1}$ with the preparative column. The product fractions were lyophilized.

M2A: Retention time (gradient C) $=35.2 \mathrm{~min}$ MALDI-TOF $(\mathrm{m} / \mathrm{z})$ found 1632; calculated 1632.

M2B: Retention time (gradient C) $=40.3 \mathrm{~min}$ MALDI-TOF $(\mathrm{m} / \mathrm{z})$ found 1808; calculated 1805.

Reaction of oligo 1 with 3 and 4. $100 \mu \mathrm{L}$ of oligo 1 solution was mixed with $100 \mu \mathrm{L}$ of the solution of the alkoxyamine (3 or

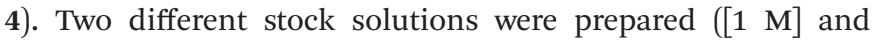
[2 $\mathrm{M}$ ] solution at $\mathrm{pH}$ 4). The reactions were followed by RP-HPLC. The reactions did not reach full conversion and many side products were observed.

M3A: MALDI-TOF $(\mathrm{m} / \mathrm{z})$ 1537; calculated 1535.

M4A: MALDI-TOF $(\mathrm{m} / \mathrm{z})$ 1567; calculated 1563.

M6A/B: reaction of oligo 1 with benzyloxyamine hydrochloride (6). $500 \mu \mathrm{L}$ of the stock solution of oligo 1 was mixed with $500 \mu \mathrm{L}$ of the freshly prepared solution of $6[1.0 \mathrm{M}]$ at $\mathrm{pH}=4$, $50{ }^{\circ} \mathrm{C}$. The reaction was followed by RP-HPLC and the products were purified by preparative RP-HPLC.

M6A: Retention time $40.2 \mathrm{~min}$. MALDI-TOF $(\mathrm{m} / \mathrm{z})$ 1585; calculated 1582 (yield 12\%).

M6B: Retention time $50.2 \mathrm{~min}$. MALDI-TOF $(\mathrm{m} / \mathrm{z})$ 1706; calculated 1705 (yield 2\%).

Reaction of oligo 2 with benzyloxyamine hydrochloride (6). To $200 \mu \mathrm{L}$ of oligo $2[200 \mu \mathrm{M}]$ was added $200 \mu \mathrm{L}$ of the stock solution of alkoxyamine $6([1.0 \mathrm{M}], \mathrm{pH}=4)$. The reaction reached $90 \%$ conversion after 5 days. The product was analyzed and purified by RP-HPLC.

Retention time $=44.0 \mathrm{~min}$ MALDI-TOF $(\mathrm{m} / \mathrm{z}) 2534$; calculated 2538 (yield 10\%).

M7A: reaction of oligo 1 with $\boldsymbol{p}$-azidobenzyloxyamine hydrochloride (7). $500 \mu \mathrm{L}$ of the stock solution of $7([0.5 \mathrm{M}], \mathrm{pH}=4)$ was added to $500 \mu \mathrm{L}$ of the oligo 1 stock solution. The reaction was followed by RP-HPLC and almost complete conversion (98\%) was achieved after 3 days. The product was purified by size exclusion chromatography (Sephadex G 15, eluting with TEAA buffer) and lyophilized to give M7A.

M7A: Retention time $43.5 \mathrm{~min}$ MALDI-TOF $(\mathrm{m} / \mathrm{z})$ 1624; calculated 1623 .

\section{General procedure for click reaction}

Before use, all the solutions were flushed with nitrogen for 10-15 min. The azido-modified M7A was dissolved in $600 \mu \mathrm{L}$ of $\mathrm{ddH}_{2} \mathrm{O}$.

The catalyst solution was prepared by dissolving $\mathrm{CuSO}_{4} \cdot 5 \mathrm{H}_{2} \mathrm{O}(2.5 \mathrm{mg}, 0.01 \mathrm{mmol})$ and sodium ascorbate (19.8 $\mathrm{mg}, 0.1 \mathrm{mmol}$ ) in $1.5 \mathrm{~mL}$ of $\mathrm{ddH}_{2} \mathrm{O}$, followed by addition of monophos $(4.1 \mathrm{mg})$ in $500 \mu \mathrm{L}$ of DMSO. This solution was allowed to stir for 10-15 $\mathrm{min}$ and then used in the click reaction.

M8A. $100 \mu \mathrm{L}(0.91 \mathrm{mmol})$ of phenylacetylene (15) was dissolved in $500 \mu \mathrm{L}$ of DMSO. $100 \mu \mathrm{L}$ of this solution was added to the DNA solution and after stirring for $5 \mathrm{~min}, 125 \mu \mathrm{L}$ of the $\mathrm{Cu}(\mathrm{I})$ catalyst solution was added. The reaction was stirred for
$2 \mathrm{~h}$ at room temperature. The mixture was lyophilized and then purified by preparative reversed phase HPLC using gradient A, to give M8A (retention time $=50.5 \mathrm{~min}$ ) in $15 \%$ yield after 2 steps. MALDI-TOF $(\mathrm{m} / \mathrm{z})$ 1726; calculated 1725 .

M9A. $2 \mathrm{mg}(0.007 \mathrm{mmol})$ of the alkyne modified dansyl derivative 16 was dissolved in $100 \mu \mathrm{L}$ of DMSO. $100 \mu \mathrm{L}$ of the solution of the alkyne was added to the DNA and after $5 \mathrm{~min}$ of stirring together, $125 \mu \mathrm{L}$ of the $\mathrm{Cu}(\mathrm{I})$ catalyst solution was added. The reaction was stirred for $2 \mathrm{~h}$ at room temperature and was then lyophilized. Purification by preparative RP-HPLC using gradient A (retention time $=53.0 \mathrm{~min}$ ) furnished M9A in a yield of $14 \%$ over 2 steps. MALDI-TOF $(\mathrm{m} / \mathrm{z}) 1917$; calculated 1911.

\section{Acknowledgements}

The authors thank the European Research Council (ERC starting grant no. 280010) and the Ubbo Emmius Foundation for financial support. G.R. gratefully acknowledges support from the Ministry of Education, Culture and Science (Gravitation program 024.001.035). Dr W. Szymanski is thanked for kindly providing the dansyl derivative 16.

\section{Notes and references}

1 (a) T. J. Bandy, A. Brewer, J. R. Burns, G. Marth, T. N. Nguyen and E. Stulz, Chem. Soc. Rev., 2011, 40, 138; (b) P. W. K. Rothemund, Nature, 2006, 440, 297; (c) N. C. Seeman, Nature, 2003, 421, 427.

2 M. Hocek and M. Fojta, Chem. Soc. Rev., 2011, 40, 5802.

3 S. H. Weisbrod and A. Marx, Chem. Commun., 2008, 5675.

4 (a) N. Sancho Oltra and G. Roelfes, Chem. Commun., 2008, 6039; (b) L. Gjonaj and G. Roelfes, ChemCatChem, 2013, 5, 1718.

5 M. Kwak and A. Herrmann, Chem. Soc. Rev., 2011, 40, 5745.

6 (a) S. L. Beaucage and R. P. Iyer, Tetrahedron, 1993, 49, 1925; (b) C. B. Reese, Org. Biomol. Chem., 2005, 3, 2851; (c) A. H. El-Sagheer and T. Brown, Acc. Chem. Res., 2012, 45, 1258.

7 (a) M. Hocek and M. Fojta, Org. Biomol. Chem., 2008, 6, 2233; (b) R. Kranaster and A. Marx, ChemBioChem, 2010, 11, 2077.

8 S. Klimaśauskas and E. Weinhold, Trends Biotechnol., 2007, 25, 99.

9 (a) G. Pljevaljcic, F. Schmidt and E. Weinhold, ChemBioChem, 2004, 5, 265; (b) Z. Liutkevičiūte, E. Kriukiene, I. Grigaityte, V. Masevičius and S. Klimašauskas, Angew. Chem., Int. Ed., 2011, 123, 2138.

10 C. Song and C. He, Acc. Chem. Res., 2011, 44, 709.

11 M. Di Antonio, F. Doria, S. N. Richter, C. Bertipaglia, M. Mella, C. Sissi, M. Palumbo and M. Freccero, J. Am. Chem. Soc., 2009, 131, 13132. 
12 G. M. Blackburn, M. J. Gait, D. Loakes and D. M. Williams, in Nucleic acids in Chemistry and Biology, RSC, Cambridge, 3rd edn, 2006, ch. 8, pp. 302-303.

13 (a) K. Tishinov, K. Schmidt, D. Häussinger and D. G. Gillingham, Angew. Chem., Int. Ed., 2012, 51, 12000; (b) K. Tishiniov, N. Fei and D. Gillingham, Chem. Sci., 2013, 4, 4401.

14 (a) P. de Hoog, C. Boldron, P. Gamez, K. Sliedregt-Bol, I. Roland, M. Pitié, R. Kiss, B. Meunier and J. Reedijk, J. Med. Chem., 2007, 50, 3148; (b) P. de Hoog, P. M. Pitié, G. Amedei, P. Gamez, B. Meunier, R. Kiss and J. Reedijk, J. Biol. Inorg. Chem., 2008, 13, 575; (c) Ş. Özalp-Yaman, P. de Hoog, G. Amedei, P. M. Pitié, P. Gamez, J. Dewelle, T. Mijatovic, B. Meunier, R. Kiss and J. Reedijk, Chem. Eur. J., 2008, 14, 3418.

15 (a) M. Villien, S. Deroo, E. Gicquel, E. Defrancq, C. Moucheron, A. Kirsch-DeMesmaeker and P. Dumy, Tetrahedron, 2007, 63, 11299; (b) N. Tuccitto, N. Giamblanco, S. Ghosh, V. Spampinato, P. Labbé, P. Dumy, S. Quici, G. Marletta, E. Defrancq and A. Liccardello, Langmuir, 2011, 27, 8595; (c) P. Crisalli, A. R. Hernández and E. T. Kool, Bioconjugate Chem., 2012, 23, 1969.

16 A. M. Maxam and W. Gilbert, Proc. Natl. Acad. Sci. U. S. A., 1977, 74, 560 .
17 B. H. Johnston, Methods Enzymol., 1992, 212, 180.

18 (a) C. Nagata and O. Mårtensson, J. Theor. Biol., 1968, 19, 133; (b) E. I. Budowsky, E. D. Sverdlov and T. N. Spasokukotskaya, Biochim. Biophys. Acta, 1972, 287, 195.

19 M. C. Pankaskie and S. A. Stolz, Synth. Commun., 1989, 19, 339.

20 (a) M. Langecker, V. Arnaut, T. G. Martin, J. List, S. Renner, M. Mayer, H. Dietz and F. C. Simmel, Science, 2012, 338, 932; (b) Y. H. Roh, J. B. Lee, P. Kiatwuthinon, M. R. Hartman, J. J. Cha, S. H. Um, D. A. Miller and D. Luo, Small, 2011, 7, 74; (c) F. E. Alemdaroglu, N. C. Alemdaroglu, P. Langguth and A. Herrmann, Adv. Mater., 2008, 20, 899.

21 R. Huisgen, in 1,3-Dipolar Cycloaddition Chemistry, ed. A. Padwa, Wiley, New York, 1984, p. 1.

22 A. H. El-Sagheer and T. D. Brown, Chem. Soc. Rev., 2010, 39, 1388.

23 L. S. Campbell-Verduyn, L. Mirfeizi, R. A. Dierckx, P. H. Elsinga and B. L. Feringa, Chem. Commun., 2009, 2139.

24 M. T. Klapötke, B. Krumm, H. Piotrowski, K. Polborn and G. Holl, Chem. - Eur. J., 2003, 9, 687.

25 W. Trommer and M. Hendrick, Synthesis, 1973, 484. 